J. Environ. Sci.

Institute of Environmental Studies and Research - Ain Shams University

\title{
LEAD RECOVERY FROM CRYSTAL GLASS SOLID WASTES
}

Ashraf A. Abdelrehiem (1); Taha M. A. Razek $^{(1)}$; Mahmoud A. Rabbah ${ }^{(1)}$ 1) Asfour Crystal Company 2) Department of Basic science, Institute of Environmental Studies and Research, Ain Shams University. 3) Chemical and electrochemical Lab., Central Metallurgical Research and development Institute (CMRDI).

\begin{abstract}
Crystal glass has many uses such as chandeliers and vases. Crystal glass contains lead oxide with a percentage varied from 8-30\%. Some of such glass is wasted during preparation of crystal products. This waste is considered hazardous due to its content from leachable lead compounds. The aim of this work is to recover lead metal from solid waste generated from polishing and grinding step in crystal glass manufacture. Samples were collected and fused with sodium carbonate at $800-1000{ }^{\circ} \mathrm{C}$ for different periods up to 5 hours. Results revealed that heating decomposed lead compounds present in the waste to lead metal. $80 \mathrm{Wt}$. \% of lead metal was recovered at activation energy $\Delta \mathrm{E}=45.2 \mathrm{k} \mathrm{j} / \mathrm{mol}$.
\end{abstract}

Keywords: lead recovery, lead reduction, crystal glass solid waste, sodium carbonate, reducing agent.

\section{INTRODUCTION}

Industrial solid waste is the unwanted or useless solid materials resulted from industrial activities in a given area (Chandrappa et al., 2012). Management of solid waste reduces or eliminates adverse impacts on the environment and human health and supports economic development and improves quality of life (White et al., 2012). Lead is valuable metal that is used in many industrial applications (Khodair, 2015), such as lead acid 
batteries (Liu et al., 2018), lead pigments industry (Gifford, 2010), lead ceramic glazes (Molera et al., 2018).

Glass is an inorganic amorphous solid (non -crystalline) that made from inorganic substances that was heated at high temperature until melting. The molten mixture was cooled from a fused condition to form a brittle rigid glass state (Callister and Rethwisch, 2009)

Silicon dioxide ( $\mathrm{SiO} 2)$ is the main constituent of glass. Types of glass and its applications are specified according to additives to silicon dioxide.

Main types of glass are soda-lime glass, lead crystal glass, borosilicate glass, and electric glass, also called E glass (Vieitez et al., 2011).

Crystal glass is used for many applications such as hollowware including bottles and drinking glasses (Pfaender, 2012), glass jewellery products and decorative and utility objects including chandeliers ( Korensky et al., 2012).

Crystal glass solid waste (sludge) was resulted from finishing step of crystal glass manufacturing (polishing and grinding process). Wastewater containing suspended solids that generated from grinding and polishing process was collected and treated in waste water treatment plant using coagulation and flocculation processes to make all suspended solids settle down and then it was separated and dried (Elkersh, 2014). Solid wastes are classified as hazardous wastes when leaching tests results exceeds standard values (5ppm for lead) (Turianicová, 2013).

Lead recovery from crystal glass solid waste was studied by numerous researchers, but most studies concentrated on encapsulation process to produce new product that contains encapsulated waste such as foam glass 
(Elkersh, 2014). Such treatment process wasted a nonrenewable resource such as valuable lead metal.

Cathode ray tube waste is similar to crystal glass waste in some points such as lead oxides percentage and presence of lead silicate, but they are different in other constituents such as organic compounds content. Different methods used for lead recovery from CRT such as electrochemical methods, thermal reduction and chemical treatment by leaching process.

Electro-chemical methods for lead recovery include acid leaching for lead by using different acids. It was reported that diluted nitric acid was the best alternative for other acids, and then leached lead was separated by electro deposition (Pruksathorn and Damronglerd, 2005). This process is complicated and is difficult to applied for large quantities of solid waste.

Other method for lead recovery was mechanical activation and hydrothermal sulphidisation of cathode ray tube includes crushing and sieving of CRT waste then it was mechanically activated by a planetary ball-mill at speed of 500 RPM for 2 hours to reduce grain sizes of particles to particle size of $13.4 \mu \mathrm{m}$. particles at this grain size are considered activated for reaction with sulfur. Thermal energy was used for enhancing the reaction between sulfur and lead present in cathode ray tube by using $100 \mathrm{ml}$ stainless steel autoclave with a turbine impeller that operates at stirring rate 700 RPM by using temperature at $300{ }^{\circ} \mathrm{C}$ for 8 hours to reach $100 \%$ of reaction of lead with sulfur (Yuan et al., 2015). This method is also complicated and is difficult to be applied on large scale.

Carbon thermal reduction method was used to recover metallic lead. Charcoal was fused with CRT glass waste at $1200{ }^{\circ} \mathrm{C}$ to generate carbon 
monoxide that reduces lead oxide to lead metal. Lead metal is leached easily using nitric acid. The resulted waste became safe after removing lead (Mingfei et al., 2016). Other method for lead recovery was carried out by silicon carbide (SIC) with CRT waste, but this study concluded that only $20 \%$ of lead oxide can be reduced to lead metal using silicon carbide (Mingfei et al., 2016).

Lead recovery from solid waste of crystal glass industry has binary benefits, economic and environmental benefits. The aim of this work is to characterize solid waste resulted from crystal glass industry and recover maximum percentage of lead metal in such waste using sodium carbonate anhydrous as a fluxing agent.

\section{MATERIAL AND METHODS}

1) Chemicals: Sodium carbonate anhydrous is of analytical grade. It was supplied from Nasr Chemicals Co. The studied solid waste was delivered from Asfour Crystal Company (glass crystal factory).

2) Instruments: 4-digit -Analytical balance.

Furnace model: VEB Electro BAD FRANKENHA USEN with maximum temperature at $1200{ }^{\circ} \mathrm{C}$.

$\underline{\text { X-RD (X-Ray Diffraction model): Bruker's X-ray Diffraction D8-Discover }}$ instrument

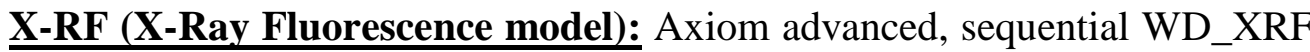
spectrometer, P Analytical 2005.

SEM model: JSM-7610F Schottky Field Emission Scanning Electron Microscope. 
J. Environ. Sci.

Institute of Environmental Studies and Research - Ain Shams University

Sieve shaker: Gilson vibratory sieve shaker model: SS-10

Laboratory test sieves: RETSCH test sieves with different mesh sizes.

\section{METHODS}

In this study twenty samples in different twenty working days were collected. The collected samples are divided into two groups. Each group was mixed to give representative sample. Solid waste was dried in open air. It was sieved using sieve shaker (Gilson vibratory sieve shaker) at different mesh sizes sieves 500, 250 and $125 \mu \mathrm{m}$. Grain size of $250 \mu \mathrm{m}$ was chosen to carry out experiments to form more homogenous mixture with anhydrous sodium carbonate powder.

Waste was analyzed by (X-RF) X-ray florescence and (X-RD) X-ray diffraction. $50 \mathrm{~g}$ solid waste with grain size of 250 microns was mixed with $50 \mathrm{~g}$ of sodium carbonate anhydrous powder passed through a sieve of 250 $\mu \mathrm{m}$ mesh size. The mixture was placed in $150 \mathrm{ml}$ silicon carbide crucible. The mixture was heated at different temperature 800, 900, 950 and $1000{ }^{\circ} \mathrm{C}$ for different time intervals 1, 2, 3, 4 and $5 \mathrm{hrs}$.

Temperature was elevated to $1000{ }^{\circ} \mathrm{C}$ with heating rate of $5{ }^{\circ} \mathrm{C} / \mathrm{min}$. by using Electric furnace. Flow diagram shown below in Figure (1) describes the process in details. The solid material resulted after fusion with sodium carbonate was crushed by ball mill at speed 400 RPM and sieved at $500 \mu \mathrm{m}$ mesh size to separate solid lead metal. EDX spectrum of solid lead metal was carried out by Emission Scanning Electron Microscope. 


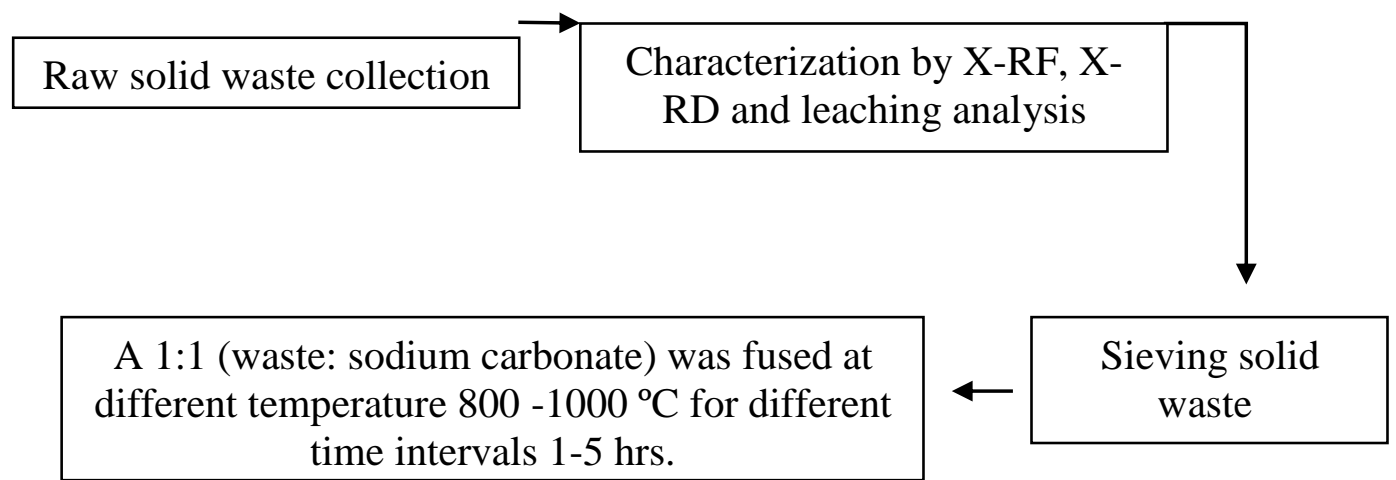

Resulted solid was crushed and sieved at 500 $\mu \mathrm{m}$ mesh size

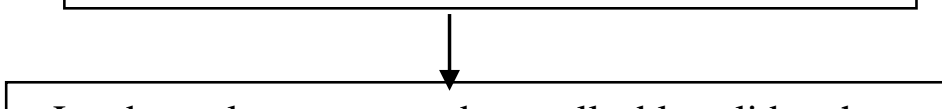

Lead metal was occurred as malleable solid at the crucible bottom that didn't crushed by ball mill and sieved at $500 \mu \mathrm{m}$ mesh size

Lead metal recovered was about $80 \mathrm{Wt}$. \% of original lead material.

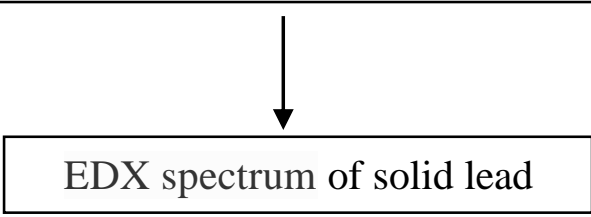

Figure (1): Flow Diagram of Experimental process 


\section{RESULTS AND DISCUSSIONS:}

1) Characterization of solid waste: The results of $X R-F$ analysis Table (1) confirm that constituents are very similar in both groups. Main constituents are lead oxide is about $20 \mathrm{Wt}$ \%, silicon oxide is $38.32 \mathrm{Wt}$. $\%$, calcium oxide is $11.8 \mathrm{Wt}$. \% and ferric oxide is $11.6 \mathrm{Wt}$. $\%$.

Table (1): XRF analysis for original solid waste samples.

\begin{tabular}{|c|c|c|c|}
\hline formula & $\begin{array}{c}\text { XRF for mixture } \\
\text { of group (1) } \\
\text { samples (\%) }\end{array}$ & $\begin{array}{c}\text { XRF for mixture } \\
\text { of group (2) } \\
\text { samples (\%) }\end{array}$ & $\begin{array}{c}\text { Average values } \\
\text { for analysis } \\
\text { results (\%) }\end{array}$ \\
\hline \hline $\mathrm{SiO} 2$ & 38.32 & 34.08 & 36.2 \\
\hline $\mathrm{PbO}$ & 21.463 & 19.1 & 20.28 \\
\hline $\mathrm{CaO}$ & 11.74 & 8.7 & 10.22 \\
\hline $\mathrm{Fe} 2 \mathrm{O} 3$ & 11.59 & 9.68 & 10.63 \\
\hline $\mathrm{K} 2 \mathrm{O}$ & 3.36 & 2.36 & 2.86 \\
\hline $\mathrm{Na} 2 \mathrm{O}$ & 3.88 & 4.94 & 4.41 \\
\hline $\mathrm{Sb} 2 \mathrm{O} 3$ & 0.22 & 0.3 & 0.26 \\
\hline $\mathrm{A} 2 \mathrm{O} 3$ & 0.39 & 1.69 & 1.04 \\
\hline $\mathrm{MgO}$ & 0.58 & 1.5 & 1.04 \\
\hline $\mathrm{CuO}$ & 0.15 & 1.05 & 0.6 \\
\hline $\mathrm{TiO} 2$ & 0.04 & 0.14 & 0.09 \\
\hline $\mathrm{NiO}$ & 0.093 & 0.19 & 0.14 \\
\hline $\mathrm{MnO}$ & 0.04 & 0.03 & 0.035 \\
\hline $\mathrm{SrO}$ & 0.036 & 0.02 & 0.028 \\
\hline $\mathrm{Cr} 2 \mathrm{O} 3$ & 0.028 & 0.01 & 0.019 \\
\hline (ignition loss) & 8.07 & 16.21 & 12.14 \\
\hline $\mathrm{All}$ consting & & & \\
\hline
\end{tabular}

All constituents in XRF analysis for both two samples of solid waste are similar except ignition loss. The ignition loss is resulted from organic compounds in the solid waste. The main source of organic compounds is gum resin material that is used to fix or stick crystal glass products on arms of grinding machine. 
The reason of variation of ignition loss between analysis of groups 1 and $2,8 \mathrm{Wt} . \%$ and 16 wt. \% respectively resulted from the variation of manual addition of gum resin material in grinding and polishing process to fix or stick crystal glass products on the machine.

Other main constituents are $\mathrm{Na} 2 \mathrm{O} 4.41$ wt. \% and $\mathrm{K} 2 \mathrm{O} 2.86$ wt. \% that are used as fluxing agent materials ( $\mathrm{Na} 2 \mathrm{CO} 3$ and $\mathrm{K} 2 \mathrm{CO} 3)$ during crystal glass manufacture to decrease melting point of crystal glass constituents and increase heating efficiency. The rest of constituents are very few that may be mixed with solid waste from other processes in the crystal glass factory.

XRD pattern below shows that lead is present as lead silicate and lead oxide in the solid waste. Lead silicates network structure depends on concentration of lead oxide regards to silicon oxide. Network in this waste is built with silicate tetrahedral with limited modification due to lead oxide addition. When lead concentration in crystal glass mixture was less than $40 \%$, it acts as network modifier (Ilyes et al., 2017).

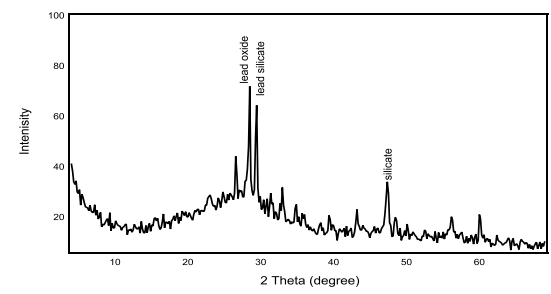

Figure (2): X-ray Diffraction pattern (XRD) for original sample of raw solid waste (sludge). 


\section{2) Effect of heating temperature on lead recovery rate at fixed heating} time (4 h): Lead recovery percentage increases with increasing temperature. Maximum recovery of lead metal was achieved at $950{ }^{\circ} \mathrm{C}$. Fusion of mixture at temperature above $950{ }^{\circ} \mathrm{C}$ reduces the recovered lead metal due to increasing evaporation of lead metal.

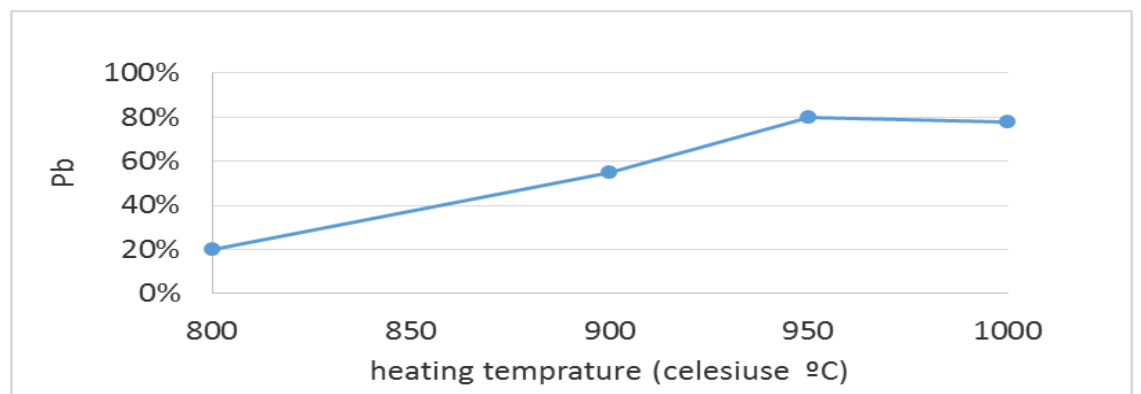

Figure (3): effect of heating temperature on lead recovery.

\section{3) Effect of time of heating on lead recovery rate at heating temperature} $\left(950{ }^{\circ} \mathbf{C}\right)$ : Heating time had great effect in this reaction. Maximum lead recovery was achieved at 4 hours. More heating time didn't improve recovery rate.

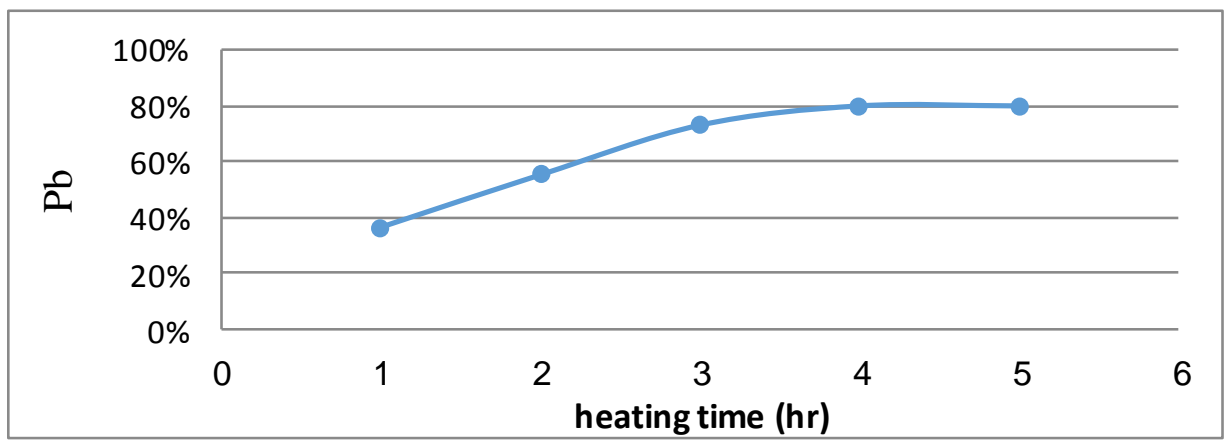

Figure (4): effect of heating time on lead recovery. 
4) Effect of temperature and time on lead recovery from waste/carbonate mixture: Lead recovery percentage increases with increasing heating temperature and heating time Figure (3). Maximum lead recovery rate was achieved at heating temperature $950^{\circ} \mathrm{C}$ for 4 hours. Heating temperature more than $950^{\circ} \mathrm{C}$ leads to reduction of recovered lead metal due to its evaporation.

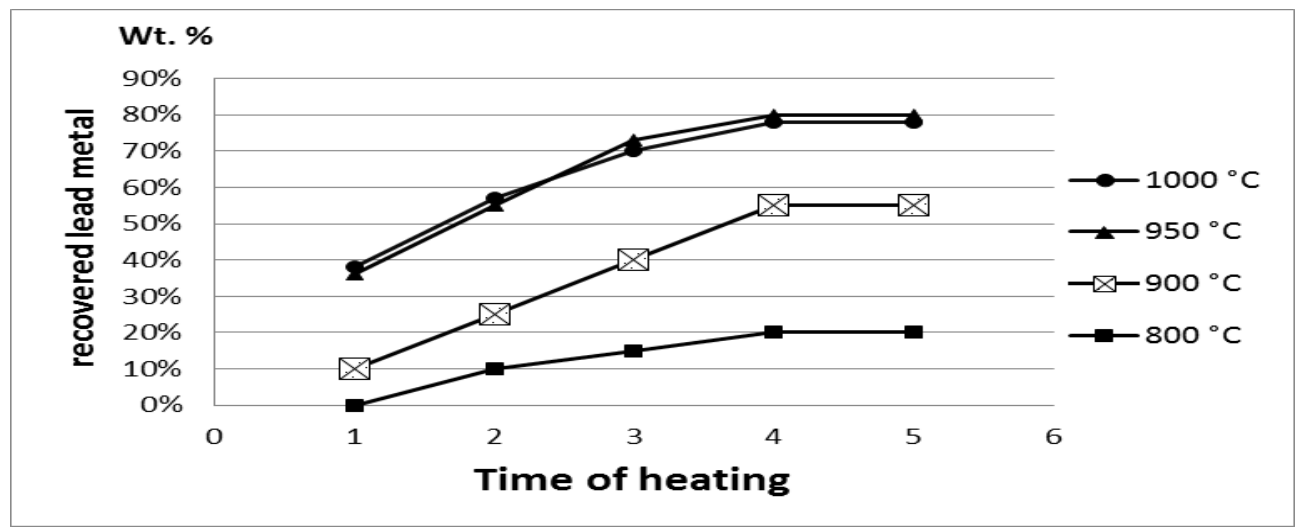

Figure (5): Weight percentage of recovered lead at different temperature and different time periods.

5) Reaction of anhydrous sodium carbonate with lead silicate: It was reported that, lead silicate melts at $760^{\circ} \mathrm{C}$ and sodium carbonate melts at $854{ }^{\circ} \mathrm{C}$ (Kacem et al., 2017). Development of the reaction was related to the increase in heating temperature. Decomposition of most organic compounds occurs when heated in range $450-800^{\circ} \mathrm{C}$ (Stephenson, 2012).

Lead silicates react with part of molten sodium carbonate to form lead carbonate and sodium silicate.

$$
\mathrm{Na}_{2} \mathrm{CO}_{3}+\mathrm{PbO}-\mathrm{SiO} 2=\mathrm{Na}_{2} \mathrm{O}-\mathrm{SiO}_{3}+\mathrm{PbCO}_{3}
$$


Lead carbonate $\left(\mathrm{PbCO}_{3}\right)$ decomposed to form lead oxide $(\mathrm{PbO})$ and carbon dioxide $\left(\mathrm{CO}_{2}\right)$ by heating effect at low temperature of $350-450{ }^{\circ} \mathrm{C}$ (Zhu et al., 2013).

$$
\mathrm{PbCO}_{3} \stackrel{\triangle}{\longrightarrow} \mathrm{PbO}+\mathrm{CO}_{2}
$$

The other part of sodium carbonate was dissociated to sodium oxide $\left(\mathrm{Na}_{2} \mathrm{O}\right)$ and carbon dioxide $\left(\mathrm{CO}_{2}\right)$ at $851^{\circ} \mathrm{C}$ (Helmenstine, 2019).

$$
\mathrm{Na}_{2} \mathrm{CO}_{3} \stackrel{851^{\circ} \mathrm{C}}{\longrightarrow} \mathrm{Na}_{2} \mathrm{O}+\mathrm{CO}_{2}
$$

Carbon dioxide that generated from this reaction reduced the percentage of oxygen in the reaction area and formed a reduction environment around the reaction that increased the chance of formation carbon mono oxide.

6) Organic compounds decomposition: Solid waste contains organic compounds that found in X-RF analysis as an ignition loss $(12 \mathrm{Wt} \%)$. Thermal decomposition of organic compounds is complex process that produces different products according to specification of organic compounds, temperature and heating time (Moldoveanu, 2009). Most organic compounds dissociate to simple products at temperature $450-800^{\circ}$ C (Stephenson, 2012). Dissociation of sodium carbonate at $851^{\circ} \mathrm{C}$ increases the concentration of carbon dioxide in the reaction surroundings and forms reduction environment. Dissociation of organic compounds in this reduction environment that contains high concentration of carbon dioxide and low concentration of oxygen causes producing carbon mono oxide that react with lead oxide to form lead metal and carbon dioxide. 


\section{Organic compounds in solid waste $=\mathrm{CO}+\mathrm{CO}_{2}+\mathrm{H}_{2} \mathrm{O}$ \\ $\mathrm{PbO}+\mathrm{CO}=\mathrm{Pb}+\mathrm{CO}_{2}$}

7) Activation energy of lead recovery reactions: Activation energy is scientific term refers to the energy required to convert reactants to products. Dependence of reaction rate on the temperature is explained by Arrhenius equation (Poole et al., 2007).

Activation energy calculations was carried out by using Arrhenius equation $\ln \mathrm{K}=-\mathrm{Ea} / \mathrm{R} \mathrm{T}+\ln \mathrm{A}$

When $\mathrm{K}$ is rate constant, Ea is activation energy, $\mathrm{R}$ is ideal gas constant, $\mathrm{T}$ is absolute temperature (kelvin) and $\mathrm{A}$ is the pre-exponential factor.

Activation energy is calculated from the slope of the curve shown below in Figure (4) according to experimental data. Calculated activation energy = $45.2 \mathrm{k} \mathrm{j} / \mathrm{mol}$.

Method of calculating rate constant $\mathrm{K}$ includes the following steps.

- When the main factor that affecting percentage of recovery was heating time we plotted the relation between heating time and recovered lead metal at each temperature value.

- Rate constant $\mathrm{K}$ equal the slop of the curve between heating time and recovered lead metal.

- Activation energy was calculated According to Arrhenius equation from the slope of the curve plotted between Ln K and (1/T).

$$
\begin{aligned}
& \ln \mathrm{K}=-\mathrm{Ea} / \mathrm{R} \mathrm{T}+\ln \mathrm{A} \\
& \ln \mathrm{K}=\ln \mathrm{A}-\mathrm{Ea} / \mathrm{RT} \\
& \mathrm{Ea} / \mathrm{R}=\text { slope } \\
& \mathrm{Ea}=\text { slope } \times \mathrm{R}
\end{aligned}
$$


Low activation energy in this reaction $(45.2 \mathrm{k} \mathrm{j} / \mathrm{mol})$ due to presence of sodium carbonate that acts as fluxing agent (Okada et al., 2012). Lead metal was occurred as ductile soft solid that didn't crush by ball mill and it was reserved on a sieve of $500 \mu \mathrm{m}$ mesh size (it didn't pass through the sieve).

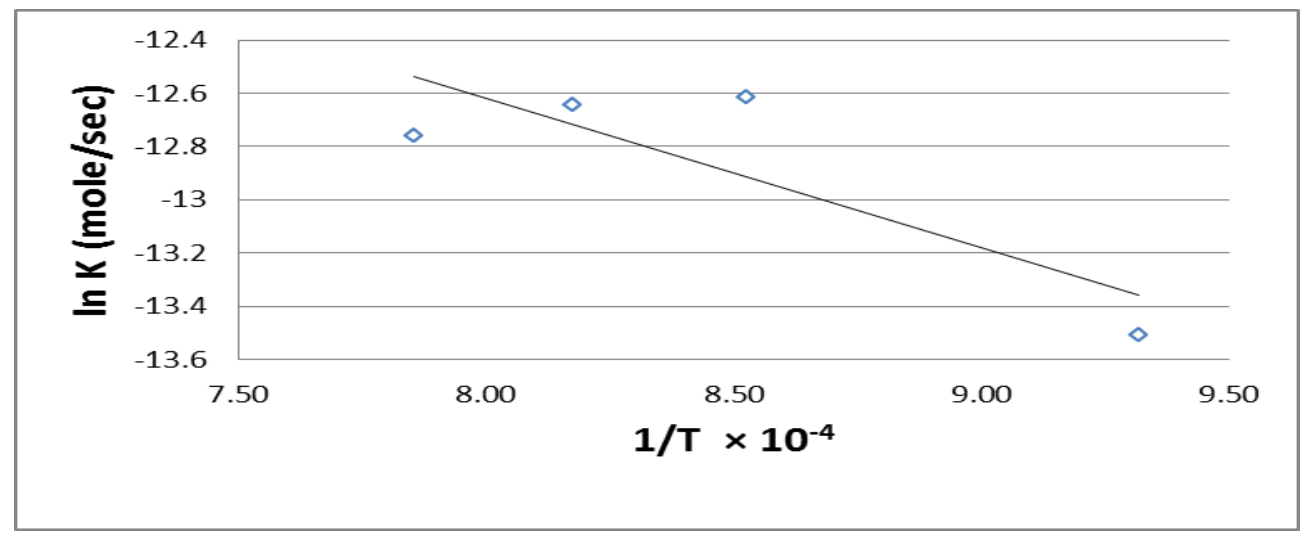

Figure (6): Chemical kinetics and activation energy calculations

8) Recovered lead metal characterization: A scanning electron microscope (SEM) was used for testing recovered metal. EDX spectrum for solid lead is shown below in Figure (7). EDX spectrum of tested metal consists of peaks corresponding to $\mathrm{Pb}$ and Oxygen in Figure (8). 


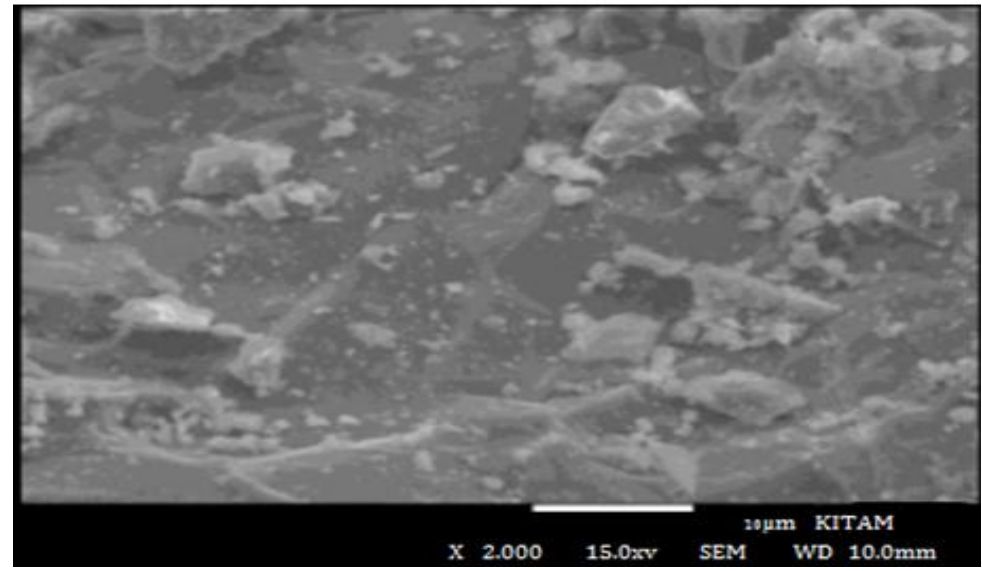

Figure (7): Field emission scanning electron microscopy (FESEM) image of lead.

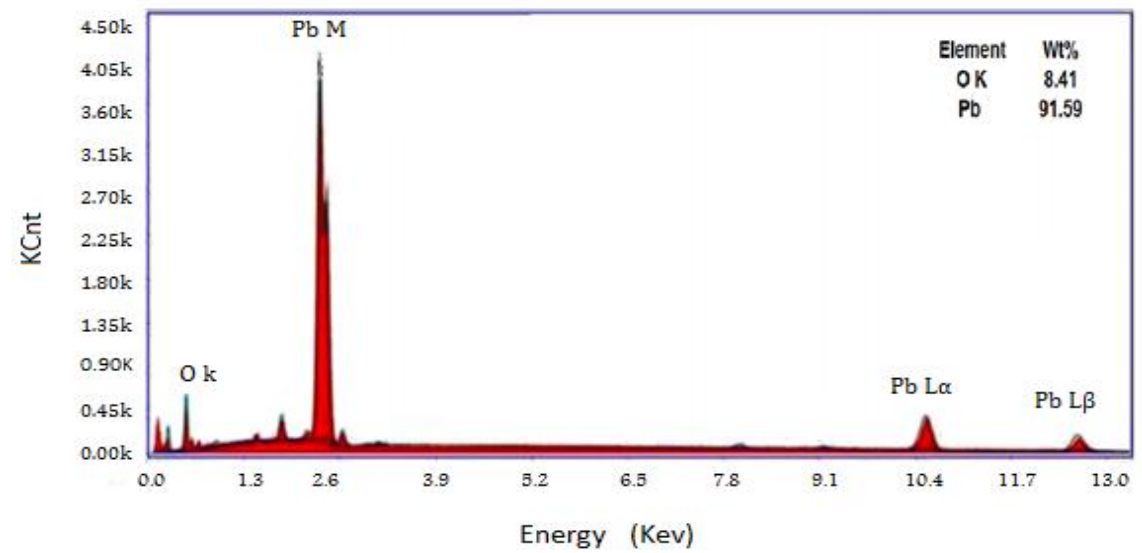

Figure (8): Spectrum data of the EDX analysis for recovered lead.

$\mathrm{Pb} \mathrm{M}$ refers to lead at excited $\mathrm{M}$ energy level, $\mathrm{O}$ k refers to oxygen at $\mathrm{K}$ energy level while $L \alpha$ and $L \beta$ other types of $L$ energy level. Lead metal is $91.59 \mathrm{Wt}$. \% while oxygen is $8.41 \mathrm{Wt}$. \%. Presence of this percentage of oxygen is due to formation of lead oxide on the metal surface due to air exposure in addition to the effect of nitric acid that was used for etching the metal surface to prepare sample for SEM analysis. Absence of additional 14

Vol. 48, No. 2 Dec. 2019 
peaks for other compounds or impurities confirms the high purity of the product.

\section{CONCLUSION}

In this study, solid waste of crystal glass industry was characterized and studied for recovery of lead metal. Solid waste was fused with anhydrous sodium carbonate that was used as a fluxing and reducing agent to recover lead metal. The main factors that affect lead metal recovery was heating temperature and heating time. Heating at $950{ }^{\circ} \mathrm{C}$ for $4 \mathrm{~h}$ was the best conditions for maximum recovery rate of lead metal $80 \mathrm{Wt} . \%$.

\section{REFRANCES}

Callister, W. D.; and Rethwisch, D. G. (2009): Materials science and engineering: an introduction- eighth edition, John Wiley and Sons, Inc.

Chandrappa, R.; and Das, D. B. (2012): Solid waste management: Principles and practice. Springer Science and Business Media.

ElKersh, H. A. F. (2014): Innovative cleaner production technique: foam glass production from lead crystal glass sludge. American university.

Gifford, D. G. (2010): Suing the Tobacco and Lead Pigment Industries: Government Litigation as Public Health Prescription. University of Michigan Press.

Helmenstine, Anne Marie, Ph.D. "Equation for the Decomposition of Sodium Bicarbonate (Baking Soda)." ThoughtCo, May. 10, 2019, thoughtco.com/decomposition-equation-for-baking-soda-604045.

Ilyes, B. K.; Laurent G.; Daniel C.; and Daniel, R. N. Structure and properties of lead silicate glasses and melts. Chemical Geology, Elsevier, 2017, 461, pp.104-114. <10.1016/j.chemgeo.2017.03.030>. <hal01632315> 
Kacem, I. B.; Gautron, L.; Coillot, D.; and Neuville, D. R. (2017): Structure and properties of lead silicate glasses and melts. Chemical Geology, 461, 104-114.

Khodair, A. (2015): Evaluating International Sources and Environmental Public Policy in Egypt: The Case of Solid Waste Management.

Korensky, J.; Sazavova, K.; and Vavrena, J. (2012): U.S. Patent Application No. 13/377,631.

Liu, K.; Yang, J.; Liang, S.; Hou, H.; Chen, Y.; Wang, J.; and Wang, J. (2018): An Emission-Free vacuum chlorinating process for simultaneous sulfur fixation and lead recovery from spent LeadAcid batteries. Environmental science and technology, 52(4), 2235-2241.

Mingfei, X.; Yaping, W.; Jun, L.; and Hua, X: Lead recovery and glass microspheres synthesis from waste CRT funnel glasses through carbon thermal reduction enhanced acid leaching process. Journal of hazardous materials, 305, 51-58, (2016).

Moldoveanu, S. C. (2009): Pyrolysis of organic molecules: applications to health and environmental issues (Vol. 28). Elsevier.

Molera, J.; López, J. C. C.; Molina, G.; and Pradell, T.: Glazes, colourants and decorations in early Islamic glazed ceramics from the Vega of Granada (9th to 12th centuries CE). Journal of Archaeological Science: Reports, 21, 1141-1151, (2018).

Okada, T.; Inano, H.; and Hiroyoshi, N.: Recovery and immobilization of lead in cathode ray tube funnel glass by a combination of reductive and oxidative melting processes. Journal of the Society for Information Display, 20(9), 508-516, (2012).

Pfaender, H. G. (Ed.). (2012):.Schott guide to glass. Springer Science and Business Media.

Poole, J. L.; Riding, K. A.; Folliard, K. J.; Juenger, M. C.; and Schindler, A. K.: Methods for calculating activation energy for Portland cement. ACI Materials Journal, 104(1), 303-311, (2007)..

Pruksathorn, K.; and Damronglerd, S.: Lead recovery from waste frit glass residue of electronic plant by chemical-electrochemical methods. Korean Journal of Chemical Engineering, 22(6), 873876, (2005).

Stephenson, R. M. (Ed.). (2012): Handbook of the thermodynamics of organic compounds. Springer Science \& Business Media. 
Turianicová, E.; Baláž, P.; Tuček, L'; Zorkovská, A.; Zeleňák, V.; Németh, Z.; and Kováč, J. (2013): A comparison of the reactivity of activated and non-activated olivine with $\mathrm{CO} 2$. International Journal of Mineral Processing, 123, 73-77.

Vieitez, E. R.; Eder, P.; Villanueva, A.; and Saveyn, H., (2011): End-ofWaste Criteria for Glass Cullet: Technical Proposals. JRC Scientific and Technical Reports.

White, P.; Dranke, M.; and Hindle, P. (2012): Integrated solid waste management: a lifecycle inventory. Springer Science and Business Media.

Yuan, W.; Meng, W.; Li, J.; Zhang, C.; Song, Q.; Bai, J.; and Li, Y. (2015): Lead recovery from scrap cathode ray tube funnel glassby hydrothermal sulphidisation. Waste Management and Research, 33(10), 930-936.

Zhu, X.; Yang, J.; Gao, L.; Liu, J.; Yang, D.; Sun, X.; and Kumar, R. V. (2013): Preparation of lead carbonate from spent lead paste via chemical conversion. Hydrometallurgy, 134, 47-53. 


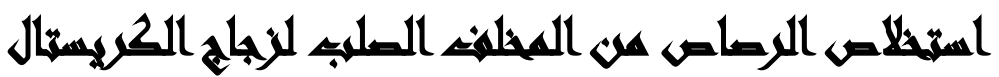

\section{[1]}

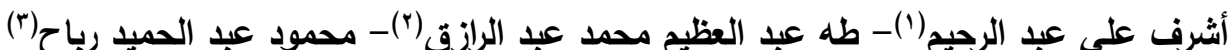

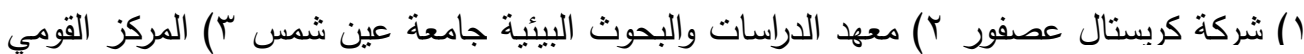

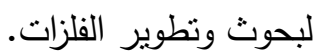

\section{المستخلص}

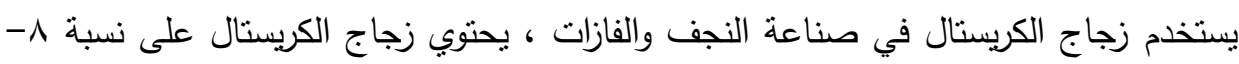

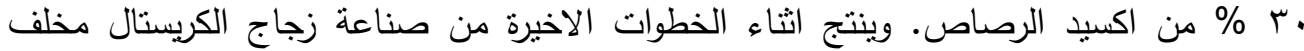

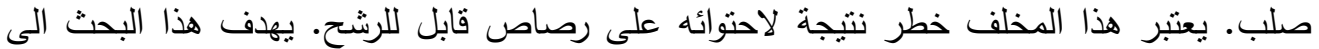

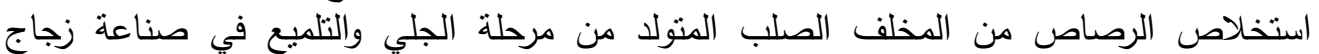

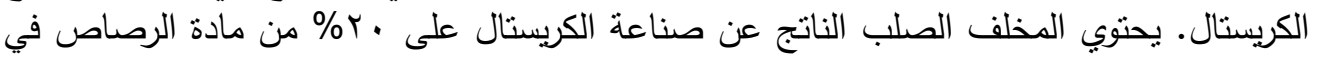
صورة سليكات رصاص واكسيد رصاص. تم جمع العينات من المخلف الصلب بحيث تكون مدناتله له

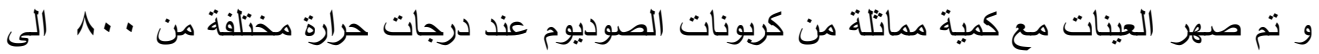

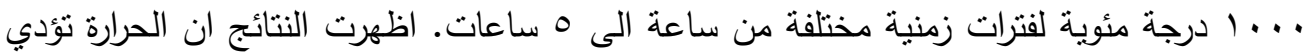

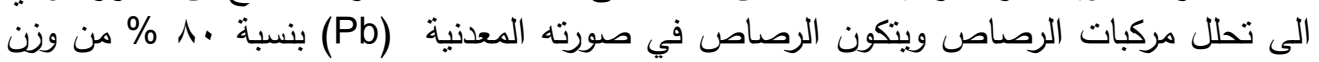

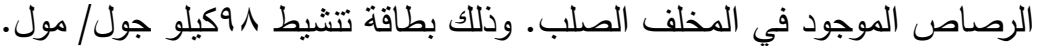
الكلمات الافتتاحية: استخلاص الرصاصناص، اختزال الرصاص، المخلف الصلب الناتج عن صناعة

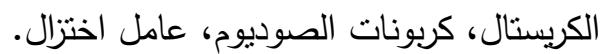

